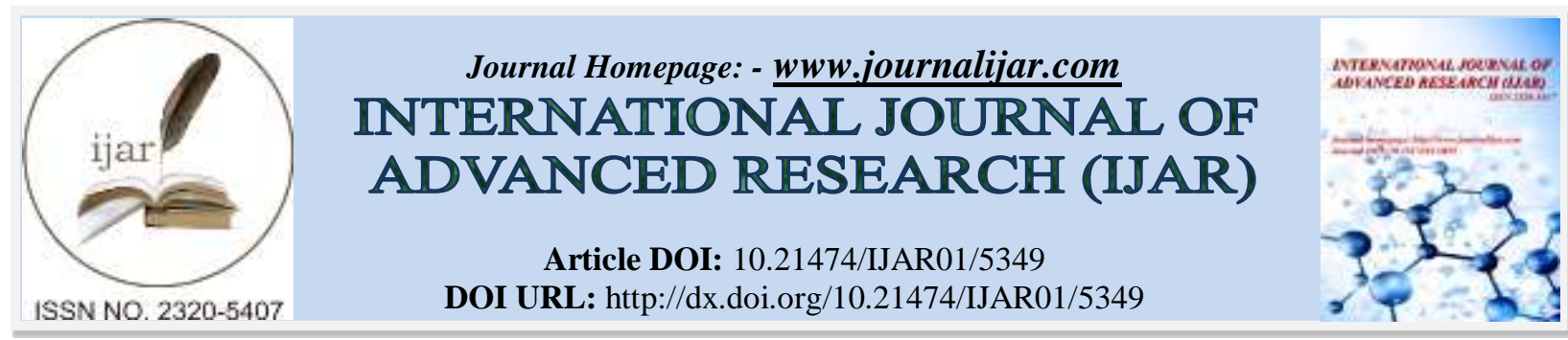

RESEARCH ARTICLE

\title{
AMELIORATIVE ROLE OF BONE MARROW MESENCHYMAL STEM CELLS AND RUTIN AGAINST ACETAMINOPHEN INDUCED HEPATOTOXICITY IN ADULT MALE RATS.
}

\section{Walaa A. M. El-Nahrawy ${ }^{1}$, Fatma A. Abu Zahra ${ }^{2}$ and Rabha E. A. EL-Dab ${ }^{3}$.}

1. Zoology Department, Women's College for Arts, Science and Education - Ain Shams University, Egypt.

2. Molecular Biology and Tissue Culture, Faculty of Medicine, Medical Research Center, Ain Shams University Cairo, Egypt.

3. Zoology Department, Faculty of Science, Omar AL-Moukhtar University, EL-Beida, Libya.

\section{Manuscript Info}

Manuscript History

Received: 07 July 2017

Final Accepted: 09 August 2017

Published: September 2017

Key words:-

Hepatotoxicity, Mesenchymal stem cells, Rutin, liver function, Oxiditive stress, Pro-inflamatory Cytokinase .

\section{Abstract}

The present study was undertaken to evaluated the therapeutic effect of bone marrow mesenchymal stem cells (MSCs) and/or rutin against acetaminophen induced hepatotoxicity in adult male albino-rats. Rats were divided into 5 groups: Group 1 (-ve control group) with no treatment; Group 2 (Acetaminophen recovery group)rats were given orally acetaminophen $750 \mathrm{mg} / \mathrm{kg}$ b.wt every $72 \mathrm{~h}$ for two weeks then left for 60 days without any treatment ; Group 3 (Acet +rutin group) rats were given orally acetaminophen $750 \mathrm{mg} / \mathrm{kg}$ b.wt every $72 \mathrm{~h}$ for two weeks then treated orally with rutin $25 \mathrm{mg} / \mathrm{kg}$ b.wt daily for 8 weeks ; Group 4 (Acet + MSCs) acetaminophen group then injected intravenously with a single dose of MSCs (1X10 6 ) cell / cm2 saline /animale ) and Group 5 (Acet +rutin and MSCs treated group) rats were given $(750) \mathrm{mg} / \mathrm{kg}$ b.wt Acettaminophen every $72 \mathrm{~h}$ for two weeks then injected intravenously with a single dose of MSCs (1X10 6 ) cell $/ \mathrm{cm} 2$ saline /animale ) and rutin. Acetaminophen adminstration caused significant increase in serum liver enzymes (AST,ALT, ALP \& $\gamma$ GT), inflammatory Cytokinase ( TNF $\alpha$, IL-6 \& IL-1 $\beta$ ) and lipid peroxidation MDA with decrease in liver Cytochrom P450 antioxidant enzymes and oxidative stress (liver SOD and GSH) as compared to control group. On the other hand, administration of rutin and/ MSCs exhibited marked amelioration in the previous parameters as compared to control group. The present study revealed that intravenous transplantation of bone marrow mesenchymal stem cells (BMSCs) or rutin administration are both successful methods for the improvement of liver functions in rats after the overdose effects of acetaminophen induced oxidative stress and inflammatory injury via retaining hepatic GSH,SOD activity ,MAD content and decreasing production of IL$6, \mathrm{IL}-1 \beta$,TNF-alph, cytochrom P450 and liver enzymes .

Copy Right, IJAR, 2017,. All rights reserved.

\section{Introduction:-}

Liver is considered a pivotal organ, involved in metabolic functions and detoxification in human body. It plays an important role in metabolic activities essential for nutrition and immune defense (Ferrigno et al.,2015). 
Hepatotoxicity is confirmed to be an important health problem that occurs due to drug metabolism or exposure to different Xenobiotics (Cheedella et al.,2014).

When given in, Acetaminophen is an antipyretic and analgesic drug that is considered as being safe under therapeutic doses. However, overdose leads to hepatotoxicity through release of cytokinase and mediator nitric oxide and tumor necrosis factor -alpha (TNF- $\alpha$ ) which has been shown to evolve tissue damage (El-Sayed et al.,2015).Also, large dose of A cetaminophen causes depletion of cellular glutathione (GSH) in liver as NAPQI react rapidly with GSH, which promote oxidation stress in conjunction with mitochondrial dysfunction, that lead to massive hepatocyte necrosis, liver failure or death.

Recently, there is a worldwide tendency to return to natural compounds and alternative medicine. Flavenoids are group of polyphenol compounds which play a remarkable role in detoxification of free radicals (Potter ,1997and Khan et al.,2012).

Rutin (quercetine-3-rutinose) is a flavonol glycoside which is comprised of the flavonol glycoside which has antioxidant properties and act as an anti-inflamatory and in myocardial preservation (Bear \& Teel,2000; Al-Enazi, 2014 and Hafez et al.,2015). Also, it plays animportant role to reduce the effect of oxidative stress which leads to inflammation, hepatotoxicity and cardiovascular disease (Lopez-Revuelta,2006 and Ashraf,2012). Moreover, rutin has restrained effects against membrane lipid peroxidation (Aleisa et al.,2013)

Stem cell are un-differentiated stem cells that are capable of dividing and renewing themselves for long time and may transform into differentiated cells .Bone marrow acts as a major source of tissue derived mesenchymal stem cells (MSCs) (Larijani et al., 2012). MSCS can travel to damaged sites and finally differentiate into cells specific to the tissue and serve as incorporated member of that specific tissue (Koc et al.,2000)

As MSCs are an attractive cell source for regenerative medicine, so, the aim of the present study was to evaluate the effectiveness of bone marrow mesenchymal stem cells (MSCs) and/or rutine on acetaminophine induced hepatotoxicity in adult male albino-rats.

\section{Materials And Methods:-}

Chemicals:-

In the present study, acetaminophen was orally administrated, at a dose of $750 \mathrm{mg} / \mathrm{kg} / \mathrm{b}$.w. every $72 \mathrm{~h}$ orally for 21 day (Chinnasamy et al.,2011). It was obtained from purchased from Sigma chemical Company (USA).

Rutin (RT) is soluble in distilled water and was administrated orally after acetaminophen treatment by the aid of gastric tube (25mg/kg b.wt .,p.o) daily for 8weeks (Shenbagam and Nalini .,2010)

\section{Animals:-}

A total number of 35 adult male albino rats were employed in the present study (150-160g). Animals were obtained from Animal House of El Salam Farm, Giza-Cairo, Egypt and were acclimatized to the laboratory conditions for two weeks prior to the start of the experiment . They were housed in metabolic cages at temperature of $24-27{ }^{\circ} \mathrm{C}$ at 48 54\% humidity, 12 hours dark/ light cycle and received standard food and water ed-libitum with fresh supplies presented daily .The experimental procedures complied with guidelines of the Committee on Care and use of Experimental Animal Resources, Ain Shams University, Cairo, Egypt.

\section{Preparation of Bone Marrow-derived Mesenchymal Stem Cells MSCs:-}

Under sterile conditions, the bone marrows of 15 male albino rats (6-week-old) were harvested by flushing the tibiae and femurs with Dulbcco's modified Eagles medium (DMEM) (Lonza Company, Swiss). The harvested cell suspension was divided into 7easy flask $25 \mathrm{~cm}$ with DMEM containing $12 \%$ fetal bovine serum(Lonza Company, Swiss), $1 \%$ penicillin- streptomycin (Lonza Company, Swiss) and 0.05\% Amphotericin B (Lonza Company, Swiss). Cells were incubated at $37^{\circ} \mathrm{C}$ in $5 \%$ humidified $\mathrm{CO} 2$; the cultured cells were examined daily by using the inverted microscope to follow up the growth of the cells and to detect the appearance of any bacterial or fungal infection among the cultured cells. After 5 days the supernatant that contained the non-adherent cells was removed by aspiration using a sterile pipette. The adherent cells were then washed twice with a sterile phosphate buffer saline (PBS). Finally $10 \mathrm{ml}$ of fresh complete media was added to the dish. MSCs were distinguished from other BM cells by their tendency to adhere to tissue culture plastic (Mok et al.,2003). The second exchange of media was done after 
3 days ( $\mathrm{Li}$ et al 2007). On day 9 the cultured cells showed confluent appearance. On day 12 the culture was washed with PBS and released with $0.25 \%$ trypsin in $1 \mathrm{mmol} / \mathrm{l}$ EDTA (Lonza Company, Swiss) $\left(4 \mathrm{~min}\right.$ at $37^{\circ} \mathrm{C}$ ). After centrifugation, the cells were re-suspended and counted with trypan blue stain $0.4 \%(100 \mu \mathrm{L}$ of cell suspension with $100 \mu \mathrm{L}$ of stain) using Neubauer haemocytometer as described by Belsey et al.,1980 MSCs were distinguished from other BM cells by their tendency to adhere to tissue culture plastic (Mok et al.,2003), and by negative expression of CD34 and positive expression of CD44 (Fig. 1) in immune-staining, described by Li et al.,2006. Briefly, the cultured cells were fixed in petri dishes on day 12 of culture by Acetone: Methanol (1:1) then covered by $\mathrm{H} 2 \mathrm{O} 2(10 \%)$. Dishes then immersed in a preheated citrate buffer solution (PH 6) and maintaining heat in a microwave, then left to cool, washed in distilled water and incubated in normal blocking goat serum. The primary antibody (CD34 or CD44 monoclonal mouse anti-human) was added and left overnight in the humidified chamber, then washed. The secondary biotinilated anti mouse antibody was added and incubated. Then, dishes were washed and covered by Streptavidin horseradish peroxidase conjugate. Color was developed using Di-amino-benzidine.

\section{Experimental design:-}

Male rats were divided into five groups 7 rats each. Group1: Control rats which recevied distilled water; Group 2: Rats were given acetaminophen $(750 \mathrm{mg} / \mathrm{kg}$ b.w., p.o) every $72 \mathrm{~h}$ over a period of 21 days then left for 60days without any treatment; Group 3: Rats receiving dose of acetaminophen for 21 days $(750 \mathrm{mg} / \mathrm{kg} \mathrm{b.w})$ every $72 \mathrm{~h}$ then treated orally with rutin $25 \mathrm{mg} / \mathrm{kg}$ b.w daily for 60day; Group 4: Rats received dose of acetaminophen (750mg/kg b.w., p.o) every $72 \mathrm{~h}$ for 21 day then injected (i.v) with a single dose with a single dose of MSCs (3x106 cells in 0.5 $\mathrm{ml}$ phosphate buffer saline PBS) and left for 60 days; Group 5: Rats received dose of acetaminophen (750mg/kg b.w., p.o) every $72 \mathrm{~h}$ for 21 day then treated with both rutin and MSCS for 60 days.

At the end of the experimental period, the rats were overnight fasted and sacrificed .Blood samples and liver tissue were taken into clean and dry screw capped centrifuge tubes then centrifuged at 3000rpm for 15 minutes in order to separate clear serum samples. They were then stored at $-20^{\circ} \mathrm{C}$ until used for determination of different biochemical parameters.

Assessment of inflammatory Cytokinase \& Liver Cytochrome $\mathbf{P}_{450}$.

The serum level of TNF $\alpha$, IL-1 $\beta$ IL-6 were determined using Commercially ELISA kits from Randox,U.K. according to the methods of AGgarwal \& Natarajan (1996) and liver Cytochrome $\mathrm{P}_{450}$ by Guengerich et al. (2009) were estimated by using commercial kit purchased from Randox,U.K.L

\section{Assessment of hepatotoxicity:-}

Liver enzymes (Alaninw aminotrasferase (ALT), aspertate aminotrasferase (AST), determined by a colorimetric method of Reitman and Frankel (1957), serum alkaline phosphatase(ALP) by the method of Belfield \& Goldberg (1971) and ( $\gamma \mathrm{GT})$ by the method of Szasz (1974).

\section{Assessment of antioxidant enzymes and oxidative stress.}

Sample of liver tissue were separated and homogenized in $10 \mathrm{ml}$ of phosphate buffer (PH 7.4) using centrifugation at $4000 \mathrm{rpm}$ for $5 \mathrm{~min}$ at $7{ }^{\circ} \mathrm{C}$. Homogenate was collected to use for assays. Activity of liver glutathione peroxidase (GSH) was determined according to the method of Gross et al.(1967); activity of superoxide dismutase (SOD) according to Nishikimi et al.,(1972) ; Malondialdehyde (MDA) according to the method of Botsoglou et al.(1994). using commercial kit was purchased from Randox,U.K.

\section{Histological examination of liver tissues:-}

From each rat, liver was carefully dissected and fixed in Bouin's, dehydrated in 70\%, 90\% and 100\% alcohol, cleared in xylol, embedded in paraffin wax at $60 \mathrm{Co}$. Transverse sections were cut at 5-6 microns in thickness and affixed to slides and then stained in Haematoxyline and Eosin.

\section{Statistical Analysis:-}

Data were statistically analyzed using analysis of variance (ANOVA) followed by Duncan's multiple range test. SPSS (version 16) statistical software was used for the analysis of data and $\mathrm{P}<0.05$ was taken as the level of significance. 


\section{Results:-}

Characteristics of MSCs in culture:-

After approximately 5 days in culture, cell appeared as a monolayer of broad flat cells (Fig.1a), The cells differentiated into a more spindle and fibroblastic shaped cells in culture, They reached confluence appearance at 914 days, (Fig.1b), and attached to the culture flasks. Most of cells did not express the hematopiotic cell marker, CD34 (Fig.1c) but expressed MSC markers CD44 (Fig. 1d).

Biochemical studies:-

Data present in table $(1)$ reveals a significant increase $(\mathrm{p}<0.05)$ in liver TNF $\alpha$ and IL-6 \& IL-1 $\beta$ and decrease in liver Cytochrom P450 in acetaminophen rat group as compared to control rats. Group treated with rutin and /or MSC showed significant decrease in inflammatory acetaminophen rat group.

The activity of liver SOD and GSH significantly decreased ( $\mathrm{p}<0.05)$ in acetaminophen treated group while the activity of MDA content significantly increased as compared to control group. All the treated groups (rutin and/or MSC) exhibited marked amelioration in the activities of the previous enzymes as compared to control group (Table 2).

Administration of acetaminophen markedly increased the activity of serum liver enzymes (AST,ALT, ALP \& $\gamma$ GT) as compared to control group. The present elevation in liver enzymes were significantly decreased $(\mathrm{p}<0.05)$ in rutin and/ MSC group.

\section{Histological examination of liver tissue:-}

Histological examination of liver sections of the control group showed a normal histological structure (Fig 2a).On the other hand ,histological analysis of acetaminophen recovery rats showed Internal hemorrhage vein with kupffer cells proliferation and pyknotic nuclei of hepatic cell and degenerative changes in hepatocytes with completely devoid of cytoplasmic inclusion, dilated portal vein (PV) filled with inflammatory cells (Fig 2 b\&c). Treatment of rats with rutin for 8 weeks showing regenerative changes in hepatic cell also some hepatocytes suffered persisted. Furthermore, treatment with MSCs showed liver section near to hepatic structure (Fig2 d).Finally, Liver section from acetaminophen rats after treatment with rutin and Stem cell showing normal configuration of hepatic tissue.

Table (1):- Effect of rutin and /or MSC on inflammatory Cytokinase \& Cytochrom $\mathrm{P}_{450}$ in hepatotoxicity male rats.

\begin{tabular}{|c|c|c|c|c|c|}
\hline Parameters & & TNFa & IL-6 & IL-1及 & Cyto $\mathbf{P}_{450}$ \\
\hline Control & Mean \pm SE & $8.65 \pm 0.91^{A}$ & $8.25 \pm 0.75^{\mathrm{A}}$ & $3.51 \pm 0.0 .87^{A}$ & $107.31 \pm 0.0 .87^{A}$ \\
\hline Acetaminophen (Recovery) & Mean \pm SE & ${ }_{B} 18.63 \pm 0.61$ & $28.61 \pm 0.62^{B}$ & $10.51 \pm 1.20^{B}$ & $65.51 \pm 0.0 .42^{B}$ \\
\hline Acetaminophine+Rutin & Mean \pm SE & $16.31 \pm 0.90$ & $22.21 \pm 0.82^{C}$ & $9.10 \pm 1.20^{\mathrm{C}}$ & $71.31 \pm 0.0 .61^{\mathrm{C}}$ \\
\hline Acetaminophine+MSC & Mean \pm SE & $14.30 \pm 1.01$ & $17.31 \pm 0.81^{D}$ & $7.02 \pm 1.21^{D}$ & $76.32 \pm 0.0 .61^{D}$ \\
\hline Acetaminophine+Rutin+MSC & Mean \pm SE & $\underset{E}{10.21 \pm 1.31}$ & $12.31 \pm 1.02^{\mathrm{E}}$ & $4.13 \pm 0.81^{E}$ & $85.52 \pm 0.62^{E}$ \\
\hline
\end{tabular}

Table (2):- Effect of rutin and /or MSC on liver GSH, SOD, MDA in hepatotoxicity male rats.

\begin{tabular}{|c|c|c|c|c|}
\hline Parameters & & $\begin{array}{l}\text { GSH } \\
(\mathbf{n m o l} / \mathrm{mg})\end{array}$ & $\begin{array}{l}\text { SOD } \\
\text { (U/mg protein) }\end{array}$ & $\begin{array}{l}\text { MDA } \\
(\mathbf{m u} / \mathbf{1 0 0 g})\end{array}$ \\
\hline Control & Mean \pm SE & $21.52 \pm 0.32^{A}$ & $22.32 \pm 0.82^{A}$ & $0.40 \pm 0.85^{A}$ \\
\hline Acetaminophen (Recovery) & Mean \pm SE & $7.90 \pm 0.61^{B}$ & $14.92 \pm 0.93^{B}$ & $0.98 \pm 0.72^{B}$ \\
\hline Acetaminophine+Rutin & Mean \pm SE & $9.62 \pm 0.50^{C}$ & $18.21 \pm 0.82^{C}$ & $0.85 \pm 0.71^{\mathrm{C}}$ \\
\hline Acetaminophine+MSC & Mean \pm SE & $11.60 \pm 0.32^{D}$ & $19.73 \pm 0.72^{D}$ & $0.78 \pm 0.71^{D}$ \\
\hline Acetaminophine+Rutin+MSC & Mean \pm SE & $15.65 \pm 0.32^{\mathrm{E}}$ & $21.21 \pm 0.62^{E}$ & $0.60 \pm 0.70^{E}$ \\
\hline
\end{tabular}

Values are expressed as mean $\pm \mathrm{SE} \quad \mathrm{N}=$ number of rats

- ${ }^{A, B, C, D} \&$ E Means with a common superscript within a row are significantly different $(\mathbf{P}<0.05)$. 
Table (3):- Effect of rutin and /or MSC on liver enzymes in hepatotoxicity male rats.

\begin{tabular}{|c|c|c|c|c|c|}
\hline Parameters & & $\begin{array}{l}\text { AST } \\
\text { (U/L) }\end{array}$ & $\begin{array}{l}\text { ALT } \\
\text { (U/L) }\end{array}$ & $\begin{array}{l}\text { ALT } \\
\text { (U/L) }\end{array}$ & $\begin{array}{c}\gamma \mathbf{G T} \\
(\mathbf{U} / \mathbf{L})\end{array}$ \\
\hline Control & Mean \pm SE & $127.19 \pm 1.69^{A}$ & $27.10 \pm 1.90^{A}$ & $53.80 \pm 8.58^{A}$ & $27.21 \pm 0.93^{A}$ \\
\hline Acetaminophen (Recovery) & Mean \pm SE & $180.32 \pm 3.20^{B}$ & $70.32 \pm 2.10^{B}$ & $472.80 \pm 6.77^{A}$ & $51.30 \pm 1.30^{\mathrm{B}}$ \\
\hline Acetaminophine+Rutin & Mean \pm SE & $158.62 \pm 1.72^{\mathrm{C}}$ & $49.21 \pm 1.52^{\mathrm{C}}$ & $240.80 \pm 10.68^{\mathrm{C}}$ & $42.61 \pm 0.85^{C}$ \\
\hline Acetaminophine+MSC & Mean \pm SE & $146.70 \pm 4.70^{D}$ & $40.21 \pm 1.50^{D}$ & $199.60 \pm 9.81^{D}$ & $39.15 \pm 0.95^{D}$ \\
\hline Acetaminophine+Rutin+MSC & Mean \pm SE & $135.30 \pm 3.01^{E}$ & $37.13 \pm 1.21^{\mathrm{E}}$ & $153.60 \pm 8.11^{\mathrm{E}}$ & $29.53 \pm 1.20^{\mathrm{E}}$ \\
\hline
\end{tabular}

FIG 1:- Photomicographs of mesenchaymal stem cells in culture
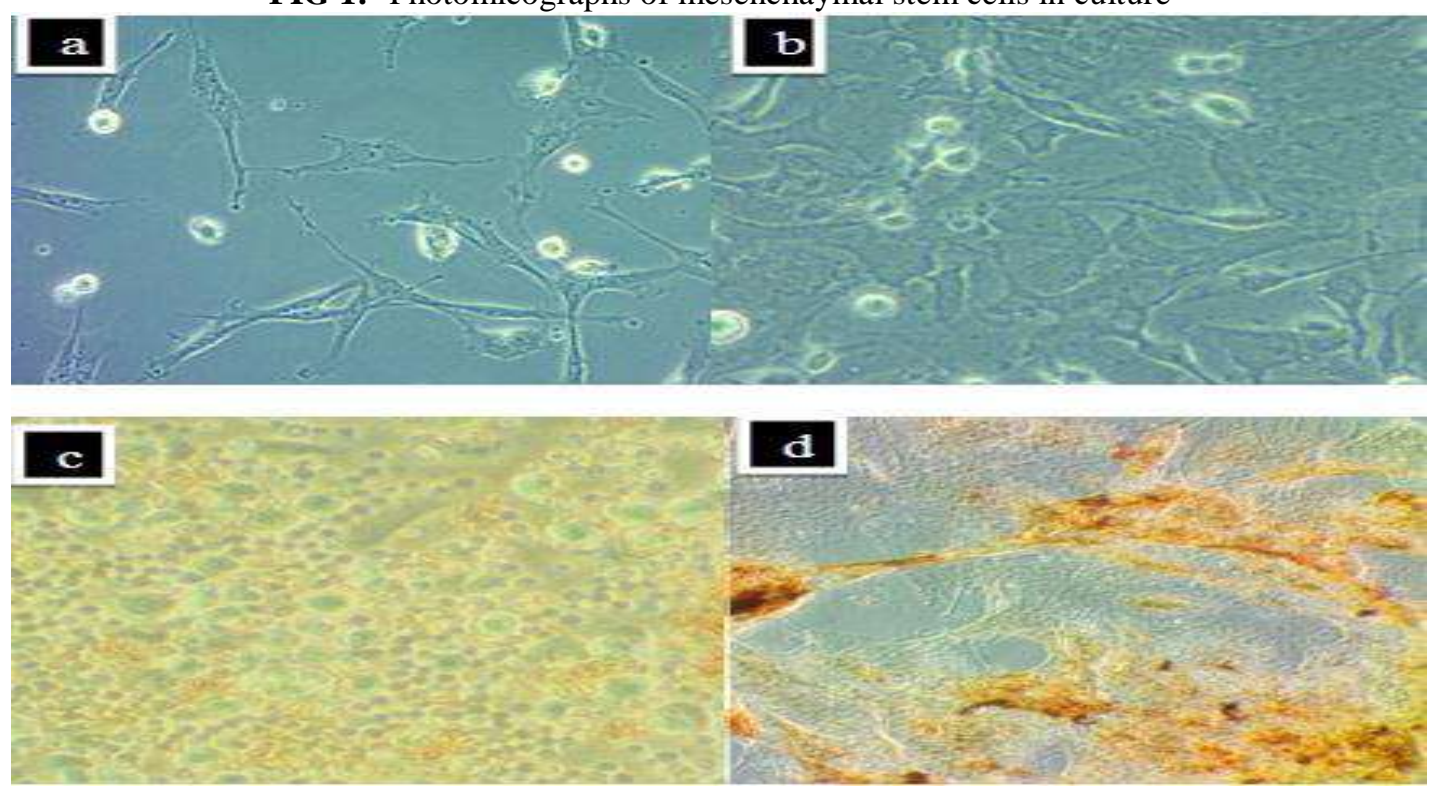

(a): Showing the MSCs at 5th day in culture,(b): At day12 the MSCs reached confluence, (c): MSCs did not express the haematopioticmarker, CD34 and (d): Cells expressed MSC markers CD44. Light inverted microscope. X400.

\section{Discussion:-}

Acetaminophen is drug with antipyretic and analgesic effects .yet overdose may lead to hepatotoxicity. Rutin acquires antioxidant properties that may compensate to such toxicity. Whether the introduction of MSCs with rutin may increase the incidence of repair or not was presently debated .

Liver is the main goal organ for metabolizing drugs and xenobiotic (Lee et al.,2010). Acetaminophen is metabolized through different pathways in livers such as, glucuronidation, sulfation and $\mathrm{P}_{450}$ activation.

Acetaminophen is one of the well know safe drugs used but when used in overdose could cause acute liver injury via formation of $\mathrm{N}$-acetyl parabenzoquineimine (NAPQI ) which is toxic metabolite by cytochrome $\mathrm{P}_{450}$. The toxic effects of NAPQI are nullified by binding to a non-protein sulfhydryl tripeptide reduced glutathione (GSH), which is metabolically a vital endogenous antioxidant in liver. The high dose of acetaminophen leads to rapid utilization and decrease in the contents of GSH and consequently ,accumulation of toxic NAPQI which exerts its effects mainly through oxidation and protein binding. NAPQI can also induce DNA strand breaks and promote apoptosis and necrosis in acetaminophen hepatotoxicity cases (Cheedella et al.,2014).

The present study illustrated significant decreases in activity of liver SOD and GSH while the activity of lipid peroxidation indicator MDA content significantly increased. These results agree with many previous authors (Chavan et al., 2013; Chen et al., 2014). Significant increase in oxidative stress is also an important reasons beside acetaminophen induced hepatotoxicity as it causes decrease in GSH contents which lead to decrease in the efficiency of the major peroxide detoxification enzymes, glutathione peroxide in liver (Kasote et al., 2012 and 
Chavan et al.,2013). The oxidative stress may also lead to oxidation of polyunsaturated fatty acids present in biomembranes that leads to destruction of structural and functional organization of this membrane. Acetaminophen intoxication result in a significant decrease in the content of GSH and SOD .

In addition , Kasote et al.,2012 reported that lipid peroxidation induced oxidative stress caused DNA damage .Rutin administration restored the alteration in the cellular enzymatic antioxidants by enhancement of antioxidant enzymes. Administration of rutin also reduced DNA damage, which is in agreement with previous studies (Hafez et al.,2015). The level of DNA damage decreases the expression of P53 and blocks cells in the G phase of the cell cycle that gives the cells additional time to repair DNA damage.

The present data investigated liver dysfunctions which were represented by increase in the activity of serum liver enzymes (AST,ALT, ALP and $\gamma$ GT) and decreased Cytochrom $\mathrm{P}_{450}$. Presently it was observed that the administration of acetaminophen significantly increased the levels of serum marker enzymes $(\mathrm{P}<0.05)$ which indicate the existence of liver toxicity,(Table 3). It can be attributed to NAPQI induced membrane damage that leads to release of the enzyme into circulation.Accordingly, high levels of liver enzymes indicates liver cell inflammation such as that caused by acetaminophen. Raised levels of serum enzymes and liver tissue Cytochrom $\mathrm{P}_{450}$ are indicative of cellular leakage and loss of functional integrity of cell membrane in liver.(Cheedella et al.,2014). ALT is more specific to the liver which can indicate liver injury (Ferrigno et al.,2015)

Moreover, after treatment with rutin the pathological increase in liver enzymes was significantly restored that may be due to flavonoids and phenolic acids in rutin which induce detoxifying enzymes to promote the elimination of toxic compounds (Kumar \& Pandey,2013).

It has been reported that mesenchymal stem cells, MSCs when transplanted systemically, were able to recognize and migrate to sites of injury, suggesting that they had migratory capacity. Thus, MSCs home into the damaged site and finally differentiate into cells specific to the tissue and serve as an integrated member of the tissue, thereby contributing toward tissue repair (Kuroda et al.,2011).

IL-6 , TNF-alpha and IL-1 $\beta$, are proinflammatory cytokines that are considered as mediators for regulation of many biomarkers such as C-reactive protein (CRP). In the present study acetaminophen treatment increases the release of these cytokines, however, the treatment with (MSCs) and/or rutin decreased hepatic formation of these inflammatory cytokines. So, the anti-inflammatory action of (MSCs) and/or rutin may be due to its inhibitory effects on production of cytokines (El-Sayed et al.,2015).

Chen et al.(2014) added that the increased IL-6, IL-1 $\beta$ and TNF-alpha in acetaminophen treated animals may be attributed to neutrophil accumulation that leads activation of liver, stimulate macrophage and hepatocyte production of nitric oxide thus stimulating acetaminophen -induced hepatotoxicity. The present result indicate that hepatocyte were injured and implied that neutrophil and macrophage were activated to enhance inflammatory reactions. However, the treatment with rutin or MSCs substantially decreased hepatic IL-6, IL-1 $\beta$ and TNF-alpha generation thus incurring liver repair from inflammation via diminishing the activation of neutrophil ,monocytes and macrophages (Chen et al.,2014).

Several studies have demonstrated that the migration of MSC to the injured tissues is dependent on CD44 expression on MSC (Braun et al.,2013 \& Crop et al.,2010). This suggests that the potential role of CD44 in MSCs migration is represented in CD44 and hyaluronic acid interaction. Some researchers have reported that stem cells can regenerate various cell lineages by trans-differentiation or by a recovery through a mechanism of protection (Lange et al.,2005).

Other possible explanations for target organ regeneration and improvement in function include facilitating the release of vascular endothelial growth factor (VEGF) by stem cells, thus, increasing the blood supply to cells and helping to repair damaged tissue (Tang et al.,2006). Stem cells may also act by up-regulating the Bcl-2 gene and suppressing apoptosis (Chen et al.,2001) or by suppressing inflammation in the diseased organ via the interleukin-6 (IL-6) pathway (Wang et al.,2006) .Both of these processes are thought to contribute to the regeneration of normal cells in the damaged organ (Pai et al.,2012). In more details, some investigators discussed the paracrine effects and trophic action of MSCs during tissue repair. When lesion lead to the death of tissue-specific cells, and part of a blood vessel, Endothelial cells become activated, immune system cells are attracted to the necrotic area, and 
pericytes/MSCs become activate then Activated pericytes/MSCs migrate into the lesion site and proliferate. The proliferating MSCs secrete bioactive molecules that will exert (a) anti-apoptotic effects on tissue-specific cells, (b) immune-modulatory effects on immune system cells, (c) angiogenic effects (d) anti-scarring effects near the wound site and (e) chemo-attractant effects on other cells. MSC paracrine effects led to stimulation of tissue-intrinsic progenitors to regenerate the damaged tissue area, modulation of immune response and consequent maintenance of self-tolerance, and re-establishment of blood supply. It is important to mention that the potential rapid disappearance of infused MSC does not rule out a functional effect of the cells. It has for instance been demonstrated that the phagocytosis of dead MSC induces the generation of macrophages with a regulatory phenotype (Tallheden et al.,2003).

In the present study, the hepatic architecture of the acetaminophen-treated rats resulted in necrotic changes, inflammatory cell infiltration and vacuolization. The present result might be due to the formation of highly reactive radicals and subsequent lipid peroxidation induced by acetaminophen .Administration of rutin and or MSCs reduced the histological alteration occurred by acetaminophen. It can be attributed to antioxidant efficacy of rutin which decreased the oxidative stress leading to the reduction of histopathological alterations and restoration of liver enzymes level. Other possible explanations for target organ regeneration and improvement in function include facilitating the release of vascular endothelial growth factor (VEGF) by stem cells, thus, increasing the blood supply to cells and helping to repair damaged tissue ( Tang et al.,2006)

\section{Conclusion:-}

The most important issue of this study was that intravenous transplantation of bone marrow mesenchymal stem cells (BMSCs) or rutin administration are both successful methods for the improvement of liver functions in rats after the overdose effects of acetaminophen -induced oxidative stress and inflammatory injury via retaining hepatic GSH,SOD activity ,MAD content and decreasing production of IL-6,IL-1 $\beta$, TNF-alph, cytochrom $\mathrm{P}_{450}$ and liver enzymes .

Nevertheless, using both rutin and $\mathrm{MSC}_{\mathrm{S}}$ results in the improvement the reparative capacity rather than either alone. 

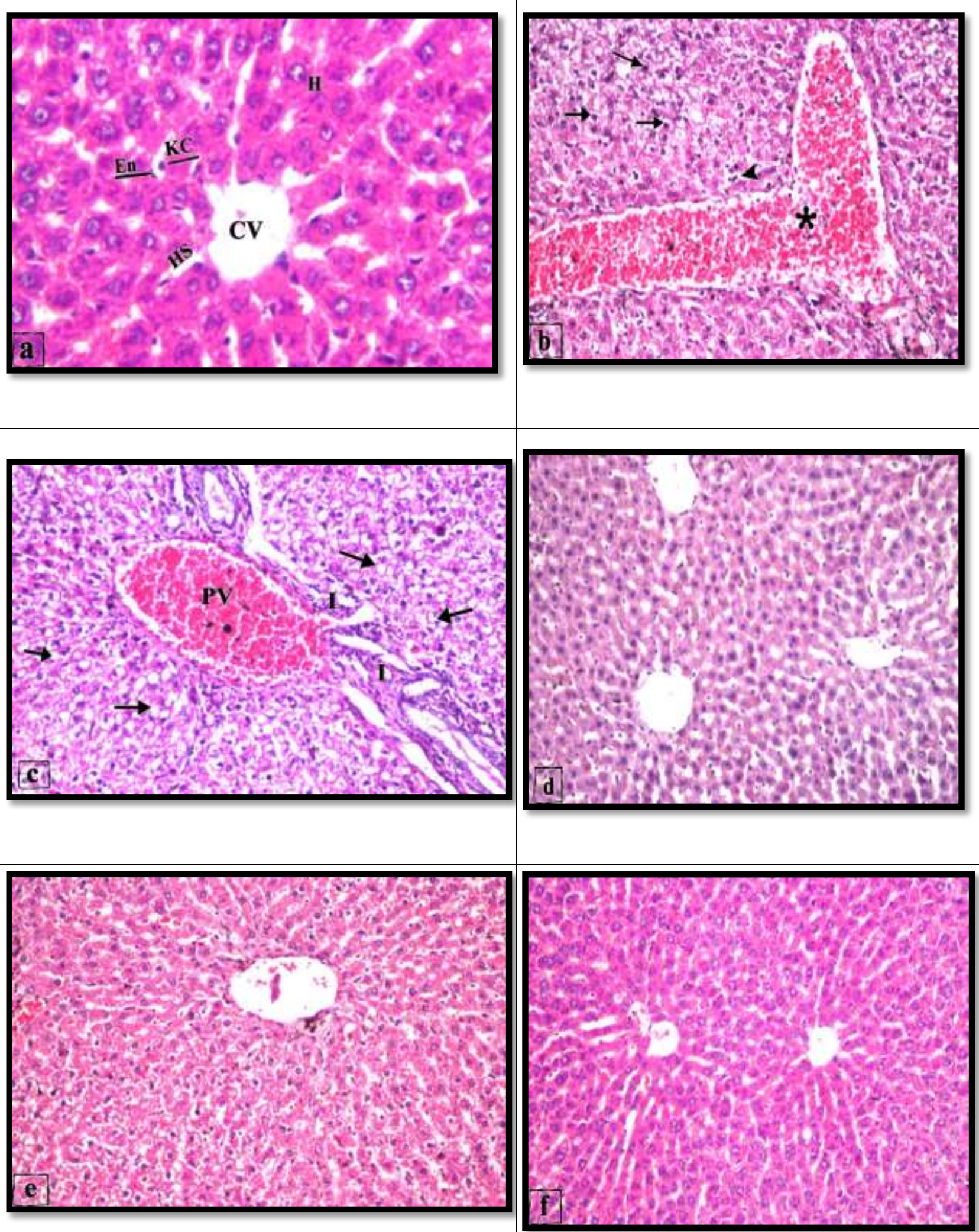
Figure2:- Cross sections of liver in experimental groups stained with H\&E, 40×. (a): normal control showing normal liver architecture with polygonal hepatocytes $(\mathrm{H})$ surrounds central vein $(\mathrm{CV})$ and separated by hepatic sinusoids (HS); the hepatic sinusoids are lined with flat endothelial cells (En) and Kupffer cells (KC). (b): Recovery group showing Internal hemorrhage vein $(*)$, kupffer cells proliferation (arrow head)and pyknotic nuclei of hepatic

cell (arrows). (c): Recovery group showing degenerative changes in hepatocytes with completely devoid of cytoplasmic inclusion (arrows) and dilated portal vein (PV) filled with inflammatory cells (I). (d):Liver section from acetaminophen + rutin treated group showing regenerative changes in hepatic cell also some hepatocytes suffered persisted. (e):Liver section from acetaminophen rats after treatment with Stem cell showing near to hepatic structure. (f): Liver section from acetaminophen rats after treatment with rutin and Stem cell showing normal configuration of hepatictissue.

\section{Reference:-}

1. Aggarwal, B. , Natarajan, K.(1996): Tumor necrosis factors: developments during the last decade. Eur. Cytokine. Netw., 7(2):93-124.

2. Al -Enazi, M.,(2014): Protective Effects of Combined Therapy of Rutin with Silymarin on ExperimentallyInduced Diabetic Neuropathy in Rats.Pharmacology \& Pharmacy , 5,876-889.

3. Aleisa,A., Abuohashish,H., Ahmed,M., Al -Rejaie,S., Alkhamees,O., Alroujayee,A.(2013): Ameliorative effects of rutin and ascorbic acid combination on Hypercholesterolemia -induced hepatotoxicity in female rats.African Journal of Pharmacy and Pharmacology ,7(6), 280-288.

4. Ashraf ,J ., Siddique ,J ., Mirani ,N.,Rub,A.(2012): Protective effect of rutin against carbon tetrachloride induced hepatotoxicity in mice. Int. J. Drug Dev. \& Res., 4 (2): 352-357.

5. Bear,W.L.,Teel,R.W.(2000): Effects of citrus flavonoids on the mutagenicity of heterocyclic amines and on cytochrome P450 activity. Anticancer Res, 20(58):3609 -14.

6. Belfield ,A., Goldberg, D.M.(1971):Revised assay for serum phenyl phosphatase activity using 4-aminoantipyrine. Enzyme. ,12(5):561-73.

7. Belsey, M.A., Moshissi, K.S., Eliasson, R., Paulsen, C.A., Callegos, A.J. , Prasad, M.R.(1980): Laboratory manual for the examination of human semen and semen cervical mucus interaction. Press concern, 1980.

8. Botsoglou, N. A., Fletouris, G. E., Papageorgiou, V. N., lopoulos, A. A. G. Trakatellis,A.G.(1994):A rapid, sensitive, and specific thiobarbituric acid method for measuring lipid peroxidation in animal tissues, food, and feedstuff samples. The Journal of Agricultural and Food Chemistry,42:1931-1937

9. Braun, J., Kurtz, A., Barutcu, N., Bodo, J., Thiel, A., Dong, J. (2013) :Concerted regulation of CD34 and CD105 accompanies mesenchymal stromal cell derivation from human adventitial stromal cell. Stem Cells Dev, 22(5), 2013, 815-27.

10. Chavan ,V., Bhargava, S., Kamble, A.(2013): Temporal modulation of oxidant and antioxidative responses in Brassica carinata during $\beta$-aminobutyric acid-induced resistance against Alternaria brassicae. Physiol, Mol, Plant, Pathol., 83:35-39.

11. Cheedella, H.K., Alluri, R. and Mohan, K. G.(2014): Hepatoprotective effect of ethanolic extract of Swertia chirayata on paracetamol induced liver damage in albino rats. World Journal of Pharmacy and pharmaceutical Sciences, 3, (8): 612-621.

12. Chen, Z. ,Wang, K., Ai, Y., Li, W. , Gao, H., Fang, C.(2014):The effects of railway transportation on the enrichment of heavy metals in the artificial soil on railway cut slopes.Environ. Monit. Assess., 186, 1039-1049

13. Chen, Z., Chua C.C., Ho, Y.S., Hamdy, R.C. , Chua, B.H.(2001): Overexpression of Bcl-2 attenuates apoptosis and protects against myocardial I/R injury in transgenic mice. The American Journal of Physiology-Heart and CirculatoryPhysiology, 280 (5), 2001, H2313-H2320.

14. Chinnasamy,A.,Balasubramanium,R.,Jajapalu,K.(2011): Protective effect of Pisonia aculeate on paracetamol induced hepatotoxicity in rats.J.Exp.Integr.Med.,167-172.

15. Crop, M.J., Baan, C.C., Korevaar, S.S., Ijzermans, J.N., Pescatori, M .,Stubbs, A.P.(2010): Inflammatory conditions affect gene expression and function of human adipose tissue derived mesenchymal stem cells. Clin. Exp. Immunol, 162(3), 474-86.

16. El-Sayed, M., Mansour,A., Nady, M.,(2015): Protective Effects of Pterostilbene against AcetaminophenInduced Hepatotoxicity in Rats.J Biochem Molecular Toxicology, 29 (1): 35-45.

17. Ferrigno,A., Pasqua, L., Berardo,C., Richelmi,P., Vairetti, M.(2015): Liver plays a central role in asymmetric dimethylarginine-mediated organ injury. World J Gastroenterol, 7; 21(17): 5131-5137.

18. Gross, R.T., Bracci, R., Rudolph, N., Schroeder, E., Kochen, JA. (1967): Hydrogen peroxide toxicity and detoxification in the erythrocytes of newborn infants. Blood. 29: 481-493. 
19. Guengerich, F.P.,Martin ,M.V.,Sohl, C.D., Cheng, Q. (2009): Measurement of cytochrome P450 and NADPHcytochrome P450 reductase. Nat. Protoc., 4:1245-1251.

20. Hafez,M., Al-Harbi,N., Al-Hoshani,A., Al Shrari,A., Al Rejaie,S., Ahmed, M., Al-Shabanah, O.(2015): Hepato-protective effect of rutin via IL-6/STAT3 pathway in CCl4-induced hepatotoxicity in rats. Biol. Res. , 48(1): 30 .

21. Kasote, D. M., Hegde, M. V. , Deshmukh, K. K. (2011):Antioxidant activity of phenolic components from nbutanol fraction (PC-BF) of defattedflaxseed meal. American Journal of Food Technology 6: 604-612.

22. 22-Koc, O.N, Day, J., Nieder, M., Gerson, S., Lazarus, H.M, Krivit, W.(2002): Allogeneic mesenchymal stem cell infusion for treatment of metachromatic leukodystrophy (MLD) and Hurler syndrome (MPS-IH). Bone Marrow Transplant, 30:215-222.

23. Kuroda, Y., Kitada, M., Wakao, S. , Dezawa, M.(2011): Bone marrow mesenchymal cells: How do they contribute to tissue repair and are they really stem cells? Arch. Immunol. Ther. Exp.(Warsz), 59, 369-378.

24. Lange, C., Bassler, P. , Lioznov, M.V. (2005): Liver-specific gene expression in mesenchymal stem cells is induced by liver cells. World J Gastroenterol, 11,4497- 4504.

25. Larijani,B., Aghayan,H., Goodarzi,P., Jahani, F., Javidan,A., Dehpour, A., Fallahzadeh, K., Sayahpour,F., Bidaki,K., Babak Arjmand,B.(2015): Clinical Grade Human Adipose Tissue-Derived Mesenchymal Stem Cell Banking.Acta. Medica. Iranica., 53(9):540-546.

26. Lee, K.P., Lee, J.H., Kim, T.S., Kim, T.H., Park, H.D., Byun, J.S., Kim, M.C., Jeong, W.I., Calvisi, D.F., Kim, J.M., Lim, D.S.(2010): The Hippo-Salvador pathway restrains hepatic oval cell proliferation, liver size, and liver tumorigenesis. Proc .Natl. Acad .Sci., 4;107(18):8248-53.

27. Li, F., Wang, X., Niyibizi, C. (2007): Distribution of Single-Cell Expanded Marrow Derived Progenitors in a Developing Mouse Model of OsteogenesisImperfecta Following Systemic Transplantation. Stem cells, 25(12), 3183-3193.

28. Li, H.H., Fu, X.B., Ouyang, Y.S., Cai, C.L., Wang, J., Sun, T.Z.(2006): Adult Bone-marrow-derived mesenchymal stem cells contribute to wound healing of skin appendages. Cell Tissue Res, 14, 325-35.

29. Mok, P.L., Leong, C.F. ,Cheong, S.K.(2003): Isolation and identification of putative mesenchymal stem cells from bone marrow. Malaysian Journal of Pathology, 25, 121-27.

30. Nishikimi, M., Rao, N. A., Yogi, K., (1972): Colorimetric determination of super oxide dismutase. Biochem. Bioph. Common. (46): 849-854.

31. Pai, M., Spalding, D., Xi, F. Habib, N.(2012): Autologous bone marrow stem cells in the treatment of chronic liver diseas (review article). International Journal of Hepatology, 1-7.

32. Rahmat, A., Khan ,R.A; Khan,M., Sumaira Sahreen,S. (2012):CCl4-induced hepatotoxicity: protective effect of rutin on p53, CYP2E1 and the antioxidative status in rat. Complementary and Alternative Medicine .12:178.

33. Reitman,S. , Frankel,S. (1957): Colorimetric method for the determination of serum glutamic oxalacetic and glutamic pyruvic transaminases. Am. J. Clin. Pathol., 28(1):56-63.

34. Revuelta ,L., Gallego,S , Yagüe ,S., Llanillo, M.(2006): Membrane cholesterol contents influence the protective effects of quercetin and rutin in erythrocytes damaged by oxidative stress. Chem. Biol. Interact., 15;161(1):7991.

35. Shenbagam M., Nalini, N. (2011): Dose response effect of Shashank, K, Pandey,A.K. (2013): Chemistry and Biological Activities of Flavonoids: An Overview.The Scientific World Journal

36. Shenbagam, M, Nalini, N.(2011): Dose response effect of rutin a dietary antioxidant on alcohol -induced prooxidant and antioxidant imbalance (histopathologic study).Clin .Pharmacol., 25(4):493-502.

37. Szasz G.(1974): Methods of Enzymatic Analysis $2^{\text {nd }}$ English New York. Academic Press Inc.1974:717

38. Tallheden, T., Dennis, J.E , Lennon ,D.P. (2003): Phenotypic plasticity of human articular chondrocytes. J Bone Joint Surg, 85-A(suppl 2), 93-100.

39. Tang, J., Xie, G., Pan, J.W., Wang, M.(2006): Mesenchymal stem cells participate in angiogenesis and improve heart function in rat model of myocardial ischemia with reperfusion. European Journal of Cardio-thoracic Surgery, 30(2), 353-361.

40. Wang, M., Tsai, B.M, Crisostomo, P.R., Meldrum, D.R.(2006): Pretreatment with adult progenitor cells improves recovery and decreases native myocardial proinflammatory signaling after ischemia. Shock, 25(5), 454-459. 